\title{
Питання підвищення ефективності управління мобілізаційною підготовкою оборонного сектору національної економіки України
}

Резюме. У статті розглянуто сучасний стан управління мобілізаційною підготовкою національної економіки. Розглянуто роль керівництва центральних органів виконавчої влади, органів державної влади, інших державних органів та їх відповідальність за впровадження заходів мобілізаційної підготовки держави. Визначено можливі шляхи підвищення якості функціонування системи управління мобілізаційною підготовкою і мобілізацією національної економіки.

Ключові слова: мобілізаційна підготовка оборонного сектору національної економіки України; система управління, ресурсне забезпечення.

\section{Постановка проблеми. Система} державного управління мобілізаційною підготовкою є складовою частиною загальної системи управління державою, яка спрямовує свою діяльність також і на мобілізаційну підготовку оборонного сектору національної економіки України та ресурсне забезпечення заходів, що проводяться. Усі органи державної i недержавної влади напружено працюють для забезпечення зазначеного майже тридцять років. Нажаль ефективність цієї роботи важко признати задовільною. Прикладом цього $є$ стан справ в авіаційній галузі, кораблебудуванні, танкобудуванні тощо.

У статті пропонується розглянути проблемні питання розподілу повноважень у системі управління мобілізаційною підготовкою національної економіки, можливості впливу на стан справ, що дасть змогу надалі визначити шляхи їх вирішення.

Аналіз останніх досліджень i публікацій. У вітчизняних публікаціях [2-4] багато уваги приділяється удосконаленню системи управління мобілізаційної підготовки оборонного сектору національної економіки України, але не достатньо повно і конкретно визначені функції органів управління i обов'язки їх керівників щодо розвитку та підтримання мобілізаційного потенціалу як складової національної економіки.

У публікаціях [5, 8-11] наведені матеріали досвіду управління мобілізаційною підготовкою, які стосуються широкого спектру питань планування заходів мобілізаційної підготовки економіки, однак не розкритий механізм трансформації досвіду провідних країн світу щодо питань фінансування заходів мобілізаційної підготовки економіки держави.

Метою статті $\epsilon$ визначення шляхів підвищення ефективності управління мобілізаційною підготовкою оборонного сектору національної економіки України та ролі центральних органів виконавчої влади, органів державної влади, інших державних органів відповідальних за впровадження заходів мобілізаційної підготовки в державі.

Виклад основного матеріалу. Оборонний сектор національної економіки (OCHЕ) - специфічна частина економіки держави, до якої належать охоплені єдиним керівництвом сукупність центральних органів виконавчої влади, інших державних i недержавних органів управління, органів місцевого самоврядування, науководослідних, дослідно-конструкторських закладів, підприємств галузей національної економіки різних форм власності, на яких задіяні трудові ресурси відповідної кваліфікації, та які вирішують завдання розроблення, виробництва, модернізації i утилізації продукції військового призначення, матеріального забезпечення та надання послуг в інтересах оборони, забезпечують функціонування економіки в цілому та життєдіяльність населення.

Отже, мобілізаційні спроможності OCHE можна визначити як властивості специфічної частини економіки держави, які забезпечують розгортання військового (мобілізаційного) виробництва у визначених потребах, зміну економічних пропорцій в інтересах всебічного збільшення виробництва військової продукції, перебудову роботи певної кількості органів управління державою та виробництвом, переведення роботи інформаційного простору, трудових ресурсів, промисловості, транспорту, зв'язку, енергетики, будівництва, сільського господарства, системи медичного, ветеринарного, санітарно-епідемічного забезпечення, видобутку природних ресурсів, формування системи життєзабезпечення населення в інтересах задоволення потреб особливого періоду, забезпечення живучості та стійкості господарчого механізму держави, зміни діяльності наукових i дослідно- 
конструкторських закладів для задоволення потреб оборони тощо [3].

Мобілізаційна підготовка - комплекс організаційних, політичних, економічних, фінансових, соціальних, правових та інших заходів, які здійснюються в мирний час 3 метою підготовки національної економіки, органів державної влади, інших державних органів, органів місцевого самоврядування, Збройних Сил України, інших утворених відповідно до законів України військових формувань, а також правоохоронних органів спеціального призначення, Державної служби спеціального зв'язку та захисту інформації України та Державної спеціальної служби транспорту (далі Збройні Сили України, інші військові формування), сил цивільного захисту, підприємств, установ i організацій до своєчасного й організованого проведення мобілізації та задоволення потреб оборони держави i захисту iii території від можливої агресіі, забезпечення життєдіяльності населення в особливий період [1].

Система управління мобілізаційною підготовкою - складова частина загальної системи управління державою, яка спрямовує діяльність органів державної влади, інших державних органів, органів місцевого самоврядування, єдиної державної системи цивільного захисту на підготовку систем управління, засобів зв'язку, інформаційного забезпечення, а також фінансових і матеріально-технічних ресурсів, підприємств, установ i організацій до проведення мобілізації [1].

Діяльність у сфері мобілізаційної підготовки держави регламентують: Закони України - 15; Укази Президента України - 10; Постанови Кабінету Міністрів України - 34; Розпорядження Кабінету Міністрів України - 7; накази Міністра розвитку економіки, торгівлі i сільського господарства України - 12.

Загальне керівництво у сфері мобілізаційної підготовки і мобілізації національної економіки здійснюється Президентом України. Організаційне керівництво мобілізаційною підготовкою i мобілізацією в Україні здійснюється Кабінетом Міністрів України. Координація діяльності органів виконавчої влади 3 питань мобілізаційної підготовки та мобілізації покладається на Раду національної безпеки i оборони України [1,2].

Проте в апаратних структурах на сьогодні не функціонують потужні мобілізаційні органи для підготовки рішень, обгрунтування показників ресурсів, які потрібні, вирішення завдань організації взаємодії та контролю виконання заходів.

Координація планування, методологічне забезпечення розроблення проєктів мобілізаційних планів та довгострокових i річних програм мобілізаційної підготовки в органах виконавчої влади, інших державних органах покладається на Міністерство розвитку економіки, торгівлі та сільського господарства України, але в його структурі також відсутній спроможний мобілізаційний орган.

Мобілізаційну підготовку оборонного сектору національної економіки, як це i передбачає діюча нормативно-правова база держави, доцільно розглядати за чотирма основними напрямами, а саме:

мобілізаційну підготовку до функціонування системи управління державою в особливий період;

мобілізаційну підготовку до мобілізаційного розгортання Збройних Сил України, інших військових формувань, Оперативно-рятувальної служби цивільного захисту;

мобілізаційну підготовку до функціонування національної економіки в особливий період; мобілізаційну підготовку до функціонування системи забезпечення життєдіяльності населення в особливий період.

Перелік наведених напрямів мобілізаційної підготовки, складність завдань дають право стверджувати, що на стратегічному рівні державного управління 3 існуючими структурами управління та кадровим потенціалом можливо здійснювати тільки загальне керівництво відповідними процесами, а 3 урахуванням текучості керівних кадрів i це завдання виконувати вкрай проблематично. Це i $\epsilon$ перше не вирішене питання мобілізаційної підготовки національної економіки держави щодо підготовки до функціонування в особливий період.

Для підвищення ефективності мобілізаційної підготовки національної економіки держави пропонується розглянути 
роль керівників центральних органів державної влади, інших державних органів за основними напрямами щодо готовності економіки до функціонування в особливий період.

На сьогодні повноваження 3 питань мобілізаційної підготовки щодо функціонування системи управління державою в особливий період визначено Положенням про Офіс Президента України, затвердженого Указом Президента України від 25 червня 2019 року № 436/2019.

Основними завданнями Офісу $\epsilon$ організаційне, правове, консультативне, інформаційне, експертно-аналітичне та інші забезпечення, здійснення Президентом України визначених Конституцією України повноважень. Проте питання організації мобілізаційної підготовки щодо функціонування системи управління державою в особливий період в завданнях Офісу не визначено.

Ст. 8 Закону України "Про Раду національної безпеки i оборони України" встановлює, що на Апарат Ради національної безпеки i оборони України покладається інформаційно-аналітичне та організаційне забезпечення діяльності Ради національної безпеки i оборони України, у якій питання організації мобілізаційної підготовки до функціонування системи управління державою в особливий період також не визначені.

Ст. 5 Закону України "Про Кабінет Міністрів України” визначає повноваження у сфері національної безпеки та обороноздатності: “...здійснює керівництво єдиною системою цивільного захисту України, мобілізаційною підготовкою національної економіки та переведенням iï на режим роботи в умовах надзвичайного чи воєнного стану".

Так, відповідно до діючої правової бази, не визначено в державі єдиного центрального органу виконавчої влади, а особливо його повноваження та відповідальність у питаннях мобілізаційної підготовки щодо функціонування системи управління державою в особливий період. Зважаючи на те, що Конституція України визначає Кабінет Міністрів України вищим органом у системі органів виконавчої влади, він і має бути відповідальним за зазначене без делегування повноважень іншим.

Розглянемо питання щодо мобілізаційної підготовки національної економіки до функціонування в особливий період.

Відповідно до законодавства держави, Кабінет Міністрів України:

визначає порядок управління національною економікою України та заходи iз забезпечення iї функціонування в особливий період;

погоджує довготермінові та річні програми мобілізаційної підготовки державних органів, Автономної Республіки Крим, областей, міст Києва та Севастополя;

визначає порядок укладання договорів (контрактів) на виконання підприємствами, установами i організаціями мобілізаційних завдань (замовлень), зокрема на поставку матеріально-технічних ресурсів, виконання робіт i надання послуг, зокрема щодо поставки готової продукції, забезпечення виконання зазначених завдань (замовлень) матеріально-технічними ресурсами, а також щодо їх фінансування;

Міністерство розвитку економіки, торгівлі та сільського господарства (далі Мінекономіки України) у зазначеній сфері:

координує планування, методологічне забезпечення розроблення проєктів мобілізаційних планів та довготермінових i річних програм мобілізаційної підготовки в органах виконавчої влади, інших державних органах;

бере участь у розробленні проєктів державних програм економічного i соціального розвитку України для врахування мобілізаційних потреб держави;

координує роботу щодо: підготовки пропозицій до проєктів державних програм економічного і соціального розвитку України в частині мобілізаційної підготовки; створення, розвитку, утримання, передачі, ліквідації і реалізації мобілізаційних потужностей; створення мобілізаційного резерву матеріально-технічних і сировинних ресурсів;

контролює виконання довготермінових $\mathrm{i}$ річних програм мобілізаційної підготовки національної економіки.

Безпосереднє керівництво щодо реалізації заходів 3 мобілізаційної підготовки і мобілізації національної економіки здійснюється керівниками центральних органів виконавчої влади, інших державних органів, місцевих органів виконавчої влади та виконавчих органів сільських, селищних, міських рад. Тобто струнка логічна система [1], але: по-перше, у зазначених органів управління фінансових ресурсів на 
мобілізаційну підготовку немає; по-друге, не виправдано часто застосовуються слова "бере участь, координує, визначає”, недостатньо слова - “організовує, відповідає, вирішує питання фінансування”.

До того ж не сприяють вирішенню завдань мобілізаційної підготовки оборонного сектору національної економіки існуючи на погляд автора проблемні питання щодо формування державного бюджету. Кошториси бюджетів за рівнями управління не передбачають можливостей цільової фінансової підтримки органами виконавчої влади виробника (підприємства-виконавця мобілізаційного завдання). Наприклад, в умовах обмежених фінансових ресурсів, проблематичне централізоване придбання технологій, обладнання, сировини тощо.

Існують проблемні

питання фінансування бюджетними коштами мобілізаційної підготовки підприємств різної форми власності. Можливо було б вирішувати питання через кредитування банками, але проведення заходів мобілізаційної підготовки підприємств не надає прибутку. Як розрахуватись за кредити? Продукція, надані послуги та сплата за них з'являться в особливий період.

Вирішення питань мобілізаційної підготовки національної економіки у складі діючої економіки ускладняється незавершеністю галузевого структурування за багатьма напрямами, наприклад: танкобудування, суднобудування, автомобілебудування тощо. Відсутність повноцінного структурування за галузями не сприяє розробленню планів управління на особливий період, довготермінових мобілізаційних та інших програм розвитку збиральних та агрегатних підприємств, організації повноцінного фінансування заходів, що плануються. Мала ймовірність, що окреме підприємство в змозі добитися його цільового державного бюджетного фінансування заходів мобілізаційної підготовки.

Отже в існуючий структурі національної економіки мобілізаційну підготовку підприємств має організовувати центральний орган виконавчої влади, в інтересах якого працюватиме зазначене підприємство. Він же має укладати договори (контракти) на виконання підприємствами, установами і організаціями мобілізаційних завдань (замовлень), фінансувати заходи мобпідготовки підприємства, контролювати ефективність витрачання ресурсів, перевіряти мобілізаційну готовність.

Існують питання щодо організації мобілізаційної підготовки до функціонування системи забезпечення життєдіяльності населення в особливий період. У державі не визначено центральний орган виконавчої влади, на який покладається відповідальність за організацію, підготовку нормативноправової бази, методичне та наукове забезпечення вирішення зазначеного питання. Конкретно не встановлена відповідальність, особистий організаційний, ресурсний внесок, повноваження за місцевими, районними, територіальними та державним рівнем управління. Справа в тому, що питання організації та забезпечення життєдіяльності населення в особливий період не належать до локальної території і мають міжгалузевий характер. Наприклад, транспортне забезпечення для пошуку роботи, проїзду до міста працевлаштування тощо. Енергетичне (електроенергією) забезпечення організовано в державі від району i вище. Медичне забезпечення за видами послуг грунтується за видами послуг на багаторівневої системі. Дуже просте, на перший погляд, але дуже складне у виконанні питання забезпечення населення паливом для опалення власного житла. У державі у більшості місцевостей відсутні ліса та копальні вугілля. Існуюча система газопостачання вкрай не стійка. Тобто потрібне організаційне начало на рівні центральних органів виконавчої влади. Торговельне забезпечення за мінімально необхідною номенклатурою товарів для населення не можливо вирішити повноваженнями органів місцевого самоврядування тощо. 3 огляду на складність завдань, багаторівневість органів прийняття рішень, міжгалузевий характер виконання завдань відповідальним за організацію мобілізаційної підготовки до функціонування системи забезпечення життєдіяльності населення в особливий період має бути Кабінет Міністрів України.

Підготовка до мобілізаційного розгортання Збройних Сил України, інших військових формувань, Оперативнорятувальної служби цивільного захисту організується органами управління відповідних військових формувань і правоохоронних органів.

Міністерство оборони України $є$ головним органом у системі центральних органів виконавчої влади, яке забезпечує формування та реалізує державну політику 3 
питань національної безпеки у воєнній сфері, сферах оборони і військового будівництва у мирний час та особливий період. До повноважень Міністерства оборони України належать організація військово-технічної політики у сфері оборони, здійснення в установленому порядку координації діяльності державних органів та органів місцевого самоврядування щодо підготовки держави до оборони.

Генеральний штаб Збройних Сил України (ГШ ЗС України) визначає потреби в pecypcax. Міністерство оборони України разом 3 органами управління інших військових формувань, іншими центральними органами виконавчої влади під керівництвом Мінекономіки України готують проєкт мобілізаційного плану національної економіки України на особливий період.

Кабінет Міністрів України визначає i затверджує основні показники мобілізаційного плану національної економіки та мобілізаційні завдання (замовлення) центральним і місцевим органам виконавчої влади, іншим державним органам тощо. Нажаль на цьому повноваження та можливості впливу з боку Міністерства оборони України, ГШ ЗС України на проведення заходів матеріального забезпечення, надання послуг мобілізаційними ресурсами національної економіки закінчуються.
Уже тривалий час не працюють підприємства реального сектору економіки танкобудування,

літакобудування, суднобудування тощо. Хоча продукція зазначених підприємств вкрай необхідна державі. Наприклад, ДП “Завод імені В. О. Малишева" за певних умов виробляв сотні танків на рік, за останні роки сучасні бойові машини у достатньої кількості не виробляє, а ПАТ “АвтоКрАЗ” основний постачальник у війська (сили) автомобільної техніки - банкрот через недостатне завантаження замовленнями та скрутним фінансовим становищем. I таких прикладів багато. Імпортозаміщення майже не проводиться, робочі місця у потрібній кількості не створюються, фахівців готують недостатньо.

Проблеми, що виникли, це наслідки відсутності необхідних фінансових ресурсів у державі. (Табл. 1, 2) Наведені в таблицях показники витрат на оборону не сприяють завантаженню в потрібних обсягах промисловість України в межах державного оборонного замовлення. Держави, які за показниками валового внутрішнього продукту за оцінкою Міжнародного валютного фонду розташовані поруч з Україною взагалі не мають ВПК, мобілізаційних потужностей для забезпечення потреб оборони.

Таблиця 1

Витрати на оборону міністерств оборони деяких держав за 1999 - 2022 роки (млн дол.) [6]

\begin{tabular}{|c|c|c|c|c|c|c|c|}
\hline Рік & Чехія & Угорщина & Польща & Румунія & Росія & Україна & Німеччина \\
\hline 1999 & 1205,93 & 702,94 & 3226,56 & 955,34 & 6469,04 & 620,81 & 31185,04 \\
\hline 2000 & 1157,29 & 715,86 & 3146,11 & 935,57 & 9228,20 & 696,40 & 26924,87 \\
\hline 2001 & 1182,52 & 845,06 & 3630,65 & 985,66 & 11683,15 & 741,71 & 26231,68 \\
\hline 2002 & 1494,39 & 1079,16 & 3776,17 & 1056,14 & 13943,83 & 872,39 & 28056,59 \\
\hline 2003 & 1885,71 & 1401,56 & 4150,26 & 1250,33 & 16973,74 & 1104,81 & 33529,45 \\
\hline 2004 & 2042,09 & 1532,61 & 4778,63 & 1530,18 & 20955,41 & 1322,22 & 36353,48 \\
\hline 2005 & 2439,54 & 1596,09 & 5896,41 & 1975,98 & 27336,98 & 1680,11 & 36397,87 \\
\hline 2006 & 2449,96 & 1410,07 & 6619,41 & 2251,49 & 34517,78 & 2085,90 & 36434,56 \\
\hline 2007 & 2707,68 & 1776,46 & 8589,14 & 2607,69 & 43534,99 & 2860,87 & 41116,12 \\
\hline 2008 & 2918,70 & 1867,88 & 9349,42 & 3000,41 & 56183,79 & 3360,26 & 46459,88 \\
\hline 2009 & 2718,56 & 1475,82 & 7903,81 & 2225,15 & 51532,12 & 2320,41 & 46119,78 \\
\hline 2010 & 2497,90 & 1350,82 & 8790,17 & 2086,22 & 58720,23 & 2587,45 & 44852,96 \\
\hline 2011 & 2474,31 & 1472,07 & 9455,42 & 2379,87 & 70237,52 & 2502,30 & 46765,51 \\
\hline 2012 & 2220,61 & 1322,28 & 8986,84 & 2102,89 & 81469,40 & 2835,91 & 44470,34 \\
\hline 2013 & 2148,78 & 1280,05 & 9275,71 & 2452,51 & 88352,90 & 2895,00 & 44865,69 \\
\hline 2014 & 2022,88 & 1209,80 & 10345,15 & 2691,47 & 84696,50 & 2997,18 & 44216,06 \\
\hline 2015 & 1779,89 & 1132,48 & 10212,79 & 2580,59 & 66418,33 & 2959,58 & 37020,07 \\
\hline 2016 & 1954,94 & 1288,68 & 9164,19 & 2644,16 & 69245,31 & 2943,81 & 39724,91 \\
\hline 2017 & 2077,72 & 1463,01 & 9870,68 & 3622,07 & 66527,30 & 3246,79 & 42365,77 \\
\hline 2018 & 2710,02 & 1791,55 & 12040,67 & 4359,02 & 61387,55 & 4169,71 & 46511,57 \\
\hline 2019 & 2910,25 & 1904,37 & 11902,53 & 4944,96 & 65102,57 & 5228,93 & 49276,76 \\
\hline $2020^{*}$ & 2995,47 & 1964,44 & 12336,33 & 5144,44 & 68034,25 & 5459,34 & 50181,35 \\
\hline $2021^{*}$ & 3080,69 & 2024,51 & 12770,13 & 5343,92 & 70965,93 & 5689,75 & 51085,94 \\
\hline $2022^{*}$ & 3165,91 & 2084,58 & 13203,93 & 5543,40 & 73897,61 & 5920,16 & 51990,53 \\
\hline
\end{tabular}


Джеджерело: www.svspb.net; *- прогнозні дані.

Таблиця 2

Валовий внутрішній продукт деяких держав світу за 2018 рік (млрд дол. США), данні МВФ [7]

\begin{tabular}{|c|c|}
\hline Держава & Показник ВВП(млрд дол. США) \\
\hline Ефіопія & 80,3 \\
\hline Марокко & $11, .3$ \\
\hline Еквадор & 10,5 \\
\hline Україна & 124,6 \\
\hline Угорщина & 155,7 \\
\hline Казахстан & 170,5 \\
\hline Катар & 192,5 \\
\hline о огляду на критичність позицій для оборонного замовлення на ідентичну
\end{tabular}

поступового ресурсного забезпечення вирішення завдань оборони ГШ ЗС України пропонується визначати потребу невідкладного задоволення: першочергову, другочергову i т. ін. В умовах обмеженості ресурсів можна i потрібно поступово при відповідній політичній волі та економічній доцільності спочатку створити можливості щодо задоволення невідкладних потреб, а потім, поступово, першочергових тощо. На сьогодні, протягом 29-ти років ГШ ЗС України, виконуючи законодавчу норму, визначає i через Міністерство оборони України подає Кабінету Міністрів України потребу Збройних сил України за найскладнішим варіантом розвитку подій.

Найбільш ефективно задоволення потреб оборони держави необхідно вирішувати спочатку через державне оборонне замовлення продукції оборонного та подвійного призначення у мирний час. Це створює умови для завчасної підготовки виробництва, пошуку співвиконавців по кооперації, постачальників вузлів, агрегатів, вирішення питань 3 безперебійним отриманням сировини в потрібних обсягах i необхідної якості, підготовки трудових ресурсів. Мають бути пов'язані проєкти Державного оборонного замовлення, Державна програма розвитку озброєння i військової техніки та Стратегія розвитку оборонно-промислового комплексу України. Позитивом $є$ і те, що замовник продукції та виробник працюють без посередників (Мінекономіки). Бюджетні кошті від замовника (господаря грошей) рухаються після виконання замовлення (у більшості випадків) виконавцю на умовах складених договорів.

Покладання мобілізаційних завдань (замовлень) завдяки укладанню договорів на підприємства виконавця державного оборонну продукцію та послуги сприятиме поступовому створенню резервів необхідних потужностей.

Отже доцільно роботу системи державного оборонного замовлення, мобілізаційну підготовку підприємств організовувати центральним органом виконавчої влади в інтересах якого працюватимуть підприємства Міністерства оборони України, Міністерства внутрішніх справ України тощо.

Міністерство повинно мати повноваження на:

пошук виконавців завдань та проведення тендерів;

підготовку проєктів Постанов Кабінету Міністрів України щодо визначення мобілізаційних завдань (замовлень) центральним і місцевим органам виконавчої влади, іншим державним органам, підприємствам на особливий період; підготовку проєктів Постанов Кабінету Міністрів України щодо створення мобілізаційних потужностей;
розроблення
проєкту
Схеми

мобілізаційного розгортання виробництва оборонної продукції, виконання робіт, надання послуг в особливий період 3 визначенням підприємств-виконавців оборонного замовлення, мобілізаційних завдань (замовлень), номенклатури продукції та іiі кількості, строків початку виробництва та виходу на повну потужність, перелік суміжників та постачальників сировини;

підготовку проєкту Мобілізаційного плану за підприємства, які виробляють оборонну продукцію, виконують роботу та надають послуги в інтересах міністерства;

доведення мобілізаційних завдань (замовлень) до центральних і місцевих органів виконавчої влади, інших державних органів, підприємств на особливий період;

контроль мобілізаційної готовності виконавців мобілізаційних завдань (замовлень). 
Центральний орган виконавчої влади має укладати договори (контракти) на виконання підприємствами, установами i організаціями державного оборонного замовлення, мобілізаційних завдань (замовлень), фінансувати заходи мобпідготовки підприємства, контролювати ефективність витрачання ресурсів.

Фінансування заходів дослідноконструкторських робіт, створення виробництва, виробництво продукції в межах державного оборонного замовлення, створення резервів потужностей (мобілізаційних можливостей) здійснюється за рахунок кошторису міністерства.

Наприклад, Міністерство оборони України створює умови для:

прийняття більш виважених рішень у визначенні номенклатури продукції та послуг, які готуватимуться до виробництва та придбатимуться в умовах обмежених ресурсів; підвищення відповідальності посадових осіб за підготовку відповідних рішень, підготовку та захист позицій бюджетного запиту, витрати бюджетних коштів; гарантованого забезпечення впровадження життєвого циклу озброєння та військової техніки: науково-дослідні, дослідно-конструкторські роботи, серійне виробництво, експлуатація у військах (силах), ремонт, модернізація, утилізація; підвищення ефективності витрат бюджетних коштів; поліпшення управління мобілізаційною підготовкою оборонного сектору економіки та гнучкістю мобілізаційним розгортанням виробництва.

Висновки та напрями подальших досліджень. Отже, для удосконалення та підвищення ефективності управління мобілізаційною підготовкою оборонного сектору національної економіки України пропонується покласти відповідальність за:

мобілізаційну підготовку щодо функціонування системи управління державою в особливий період - на Кабінет Міністрів України;

мобілізаційну підготовку щодо мобілізаційного розгортання Збройних Сил України, інших військових формувань, Оперативно-рятувальної служби цивільного захисту - на Міністерство оборони України, Міністерство внутрішніх справ України; мобілізаційну підготовку щодо функціонування оборонного сектору національної економіки в особливий період 3 питань наукового, методичного, організаційного керівництва, загального планування та звітності - на Мінекономіки України;

мобілізаційну підготовку щодо функціонування системи забезпечення життєдіяльності населення в особливий період - на Кабінет Міністрів України;

мобілізаційну підготовку підприємстввиконавців державного оборонного замовлення, мобілізаційних завдань (замовлень), планування та звітність - на Міністерство оборони України, Міністерство внутрішніх справ України.

Створити в складі зазначених центральних органів виконавчої влади потужні виконавчі структури.

Удосконалити нормативно-правову базу 3 метою створення умов для ефективної подальшої роботи в зазначеній сфері.

Подальші дослідження спрямувати на моделювання роботи системи управління державою в мирний час та особливий період 3 питань мобілізаційної підготовки оборонного сектору національної економіки.

\section{СПИСОК ВИКОРИСТАННОЇ ЛІТЕРАТУРИ}

1. Про мобілізаційну підготовку та мобілізацію : Закон України від 21.10.1993 р. № 3544-XII. ВBP, 1993, № 44, 1 ст. $417 . \quad$ URL: https://zakon.rada.gov.ua/laws/show/3543-12 (дата звернення: 02.01.2021).

2. Гріненко О. І. Ворович Б. О., Кутовий О. П. Аналіз системи управління мобілізаційною підготовкою та мобілізацією національної економіки. Визначення проблемних питань іiі функціонування. Збірник наукових праџь Центру воєнно-стратегічних досліджень Національного університету оборони України імені Івана Черняховського. Київ, 2020. № 1 (68). С. 44-51.

3. Гріненко О. І., Кутовий О. П., Шапталенко М. І. Мобілізаційні спроможності оборонного сектору національної економіки України: погляди на ефективність. Збірник наукових праць Центру воєнно-стратегічних досліджень Національного університету оборони України імені Івана Черняховського. Київ, 2019. № 2(66). С. 29-34.

4. Горбулін В. П. Зубарєв В. В., Скурський П. П., Кутовий О. П. Проблемні питання формування ефективної системи управління обороннопромисловим комплексом України. Національна безпека: украӥнський вимір. 2009. № 4 (23). С. 1120.

5. Волотівський П. Б., Дупляк П. П. Щодо причин низької якості управління мобілізаційною підготовкою та мобілізацією в державі. Довготермінові програми мобілізаиійної підготовки. Їх роль у забезпеченні готовності держави до функиіонування в умовах особливого nеріоду : мат. міжвідом. наук.-практ. конф. 
м. Київ, 16 квіт. 2015 р. Київ, 2015. С. 77-83.

6. Показники ВBП країн світу. URL: https:///knoema.ru/nwnfkne/\%D0\%BC\% D0\%B8\%D1\%80\%D0\%BE\%D0\%B2\%D0\%BE\%D 0\% B9.

\%D1\%80\%D0\%B5\%D0\%B9\%D1\%82\%D0\% B8\%D0\%BD\%D0\%B3\%D1\%81\%D1\%82\%D1\%80 $\% \mathrm{D} 0 \% \mathrm{~B} 0 \% \mathrm{D} 0 \% \mathrm{BD}-\% \mathrm{D} 0 \% \mathrm{BF} \% \mathrm{D} 0 \% \mathrm{BE}-$ $\% \mathrm{D} 0 \% \mathrm{~B} 2 \% \mathrm{D} 0 \quad \% \mathrm{~B} 2 \% \mathrm{D} 0 \% \mathrm{BF}-\% \mathrm{D} 0 \% \mathrm{~B} 2-$ 2019\%D0\%B3\%D0\%BE\%D0\%B4\%D1\%83\%D1\% $81 \% \mathrm{D} 1 \% 82 \% \mathrm{D} 0 \% \mathrm{~B} 0 \% \mathrm{D} 1$ $\% 82 \% \mathrm{D} 0 \% \mathrm{~B} 8 \% \mathrm{D} 1 \% 81 \% \mathrm{D} 1 \% 82 \% \mathrm{D} 0 \% \mathrm{~B} 8 \% \mathrm{D} 0 \% \mathrm{~B}$ A\%D0\%B0 (дата звернення: 02.01.2021).

7. Рынок и мобилизационные мощности в промышленности (на примере США). URL: http://svop.ru/wp-content/uploads/2018/10/ Voenny Vestnik MFIT No3 RYNOK-IMOBILIZACIONNYE-MOSCHNOSTI. pdf (дата звернення: 04.01.2021).

8. Оцінка та управління якістю планів. URL: https://library.if.ua/book/122/8069.html (дата звернення: 04.01.2021).

9. Ширалієв Р. Ш. Проблемні питання законодавчого, нормативно-правового та організаційного характеру, що впливають на функціонування національної економіки України в особливий період та забезпечення потреб оборони. Проблеми своєчасного забезпечення Збройних Сил Украӥни озброєнням, військовою технікою, іншими матеріально-технічними засобами в особливий період. Можливі шляхи їх вирішення : мат. наук.-практ. семінару. м. Київ, 26 лист. 2015 р. Київ, 2015. С. 19-26.

10. Волотівський П. Б. Питання мобілізаційного планування національної економіки України. Зміст, принципи та підходи щодо його організації в сучасних умовах. Наука і оборона. 2018. № 2. C. 17-24.

11. Горовенко В. К., Щипанський П. В. Деякі проблеми організації мобілізаційної підготовки України. Довготермінові програми мобілізаційної підготовки. Ïх роль у забезпеченні готовності держави до функиіонування в умовах особливого nеріоду : мат. міжвідом. наук.-практ. конф. м. Київ, 16 квіт. 2015 р. Київ, 2015. С. 23-26.

Стаття надійшла до редакційної колегії 25.01.2021

\section{Issues of improving the efficiency of management of the mobilization training of the defense sector of the national economy of Ukraine}

\section{Annotation}

The system of state management of mobilization training is an integral part of the general system of state management, which directs its activities, including the mobilization readiness of the defense sector of the national economy of Ukraine, resource provision of ongoing activities.

Ways to increase the efficiency of management of mobilization training of the defense sector of the national economy of Ukraine and the role of central executive bodies, public authorities, other state bodies responsible for the implementation of mobilization training in the state are identified.

Mobilization training of the defense sector of the national economy, as provided by the current legal framework of the state, should be considered in four main areas, namely:

mobilization training for the functioning of the state management system in a special period;

mobilization training for the mobilization deployment of the Armed Forces of Ukraine, other military formations, operational and rescue service of civil defense;

mobilization training for the functioning of the national economy in a special period;

mobilization training for the functioning of the system of ensuring the livelihood of the population in a special period.

The decision of questions of mobilization preparation of national economy as a part of operating economy is complicated by incompleteness of branch structuring in many directions. Therefore, in the existing structure of the national economy, mobilization training of enterprises should be organized by the central executive body in the interests of which the enterprise will operate.

It is proposed to create powerful executive structures within these central executive bodies.

Keywords: mobilization training of the defense sector of the national economy of Ukraine; management system, resource provision. 